\title{
A Simple Technique Based on Digital Images for Determination of Nitrogen Dioxide in Ambient Air
}

\author{
Pedro Augusto de França Souza • José Lozano Araújo \\ Neto $\cdot$ Arnaldo Alves Cardoso
}

Received: 2 October 2020 / Accepted: 27 January 2021 /Published online: 12 February 2021

(C) The Author(s), under exclusive licence to Springer Nature Switzerland AG part of Springer Nature 2021

\begin{abstract}
The lockdown to prevent the coronavirus spread resulted in an immediate reduction in gas concentration worldwide. This fact shows the importance of nitrogen dioxide as a pollutant gas directly associated with human activities. For indoor exposure, $\mathrm{NO}_{2}$ has been associated with effects on the respiratory system. In outdoor environments, ozone reaches a maximum after $\mathrm{NO}_{2}$ peaks, and acid rain arises with $\mathrm{NO}_{2}$ oxidation to forms nitric acid. Therefore, monitoring the $\mathrm{NO}_{2}$ concentration in atmospheric air can help prevent respiratory diseases and lower the concentration of other atmospheric pollutants. The experiment proposed in this article uses a low-cost passive sampler for the $\mathrm{NO}_{2}$ collection. An innovative and straightforward technique to determine the gas concentration through a gel-dyed formation and based on digital image analysis RGB colors channel are split by the software ImageJ. Results of digital image analysis and spectrophotometry were statistically agreed at a $95 \%$ confidence level. The advantages of the technique include low cost, the ready availability of components, ease of use, and sensitivity. The achievable resolution of nitrogen dioxide concentrations is $9 \mathrm{ppb}$ for 24-h sampling.
\end{abstract}

Keywords Air pollution - Air quality · Digital image analysis $\cdot \mathrm{NO}_{2}$ monitoring $\cdot$ Passive sampling . Colorimetry

P. A. de França Souza · J. L. A. Neto • A. A. Cardoso $(\bowtie)$ Department of Analytical Chemistry, São Paulo State University, UNESP, Araraquara, SP CEP 14800-970, Brazil e-mail: acardoso@iq.unesp.br

\section{Introduction}

Data from satellites reveal the decline of air pollution, specifically nitrogen dioxide concentrations, over different cities in the world in 2020. This reduction, reported in various articles, coincides with its nationwide lockdown to prevent the coronavirus spread (Khoo 2020). And regions with permanently high levels of nitrogen dioxide in the air may be associated with an increased number of deaths from COVID-19 than other areas (Ogen 2020). These facts show that nitrogen dioxide could be a tracer of the effectiveness of the lockdown. The primary source of $\mathrm{NO}_{2}$ in the atmosphere is the combustion of fuels. The fossil fuels, such as coal, oil, and natural gas, and renewable sources (i.e., ethanol, biodiesel, and wood) are the primary energy sources of the world (International Energy Statistics - US Energy Information Administration (EIA) n.d.). Fuels are used every day to produce energy in the form of heat. The fuel burning is done with air, and the high temperature achieved in the combustion results in the breakdown of $\mathrm{N} \equiv \mathrm{N}$ covalent bonds. The formation of reactive nitrogen atoms promotes a chain reaction with oxygen with the production of NO. In the atmosphere, NO is rapidly oxidized to $\mathrm{NO}_{2}$. Oxidants, such as ozone, present in the atmosphere make this oxidation in $18 \mathrm{~s}$ (Finlayson-Pitts and Pitts 1997). Levels of $\mathrm{NO}_{2}$ vary worldwide, and in urban areas depend on traffic density and use of energy. Urban outdoor level pollution varies according to the time of day, the season of the year, and meteorological factors (Warashina et al. 2001). 
The $\mathrm{NO}_{2}$, which acts as a photocatalyst, oxidizes volatile organic compounds (VOC) and forms ozone and aldehyde as the reaction products. Ozone is a powerful oxidizing agent and is toxic at a concentration as low as $80 \mathrm{ppb}$ or $160 \mathrm{\mu g} \mathrm{m}^{-3}$ (World Health Organization 2000). After ozone formation, a second reaction becomes essential: the $\mathrm{HO} \bullet$ radical participates in the $\mathrm{NO}_{2}$ oxidation reaction to form nitric acid. Nitric acid modifies the acidity of the atmosphere. Part of nitric acid reacts with ammonia to increase fine particle levels (Allen et al. 2011; Giannadaki et al. 2018; Machado et al. 2008). The $\mathrm{NO}_{2}$ gas reacts in the atmosphere with the formation of $\mathrm{HNO}_{3}$ and $\mathrm{XNO}_{3}$, the main components of the dry deposition of total $\mathrm{N}$ species. Consequently, with the determination of $\mathrm{NO}_{2}$ concentration, it is possible to estimate the $\mathrm{N}$ deposition (Allen et al. 2011).

Annual mean $\mathrm{NO}_{2}$ concentrations in urban areas worldwide are generally in the range of $20-90 \mu \mathrm{g}$ $\mathrm{m}^{-3}$ (11-50 ppb) (World Health Organization 2006). The atmospheric concentration varies significantly with the potential of emission sources. Rural areas usually have lower concentrations than urban areas. Atmospheric nitrogen dioxide $\left(\mathrm{NO}_{2}\right)$ concentrations were measured in ten cities of China and Korea by passive samplers. Significant monthly variations in concentration were observed in the different cities and during the seasons. Average concentrations ranged between 10 and $30 \mathrm{ppb}$ with peak values greater than $80 \mathrm{ppb}$ (Warashina et al. 2001). The average $\mathrm{NO}_{2}$ concentration at Rawalpindi city (Pakistan) was 27 ppb. The highest values of $\mathrm{NO}_{2}$ were measured near main roads and educational institutions. The study showed that the values obtained for $\mathrm{NO}_{2}$ exceeded the annual limit value set by the World Health Organization (Ahmad et al. 2011). $\mathrm{NO}_{2}$ levels recorded in the Ciudad Real area in 2007 using passive samplers which showed an average of $21 \mu \mathrm{g} \mathrm{m}^{-3}$ ( 11 ppb) for $\mathrm{NO}_{2}$ are below the threshold values (Martin et al. 2010). The 2019 report by CETESB (São Paulo State Environmental Agency, Brazil) on air quality showed that the maximum $\mathrm{NO}_{2}$ concentration was $228 \mu \mathrm{g} / \mathrm{m}^{-3}$ (121 ppb) for São Paulo city. And the maximum recorded was $160 \mu \mathrm{g} \mathrm{m}^{-3}$ (85 ppb) for other São Paulo State regions (CETESB 2019). The ambient air concentrations in $\mathrm{NO}, \mathrm{NO}_{2}$, and $\mathrm{NO}_{\mathrm{x}}$ have decreased significantly at most world sites. The reductions in concentrations consistent with reductions in primary emissions likely arise from implementing the air quality standards (Henschel et al. 2015; Hůnová et al. 2020; Tong et al. 2015).
The indoor $\mathrm{NO}_{2}$ concentration can be affected by internal sources, the compound decay, air exchanges with outdoor air, and room size building. Exposure to high levels of NO2 may contribute to the development of acute or chronic bronchitis. It may also cause increased bronchial reactivity in asthmatic patients with chronic obstructive pulmonary disease (Arbex et al. 2007). Many studies have linked $\mathrm{NO}_{2}$ to cardiopulmonary mortality, lung cancer, and asthma exacerbations (Beelen et al. 2008; Filleul et al. 2005; Gauderman et al. 2005). The indoor concentration limit established by WHO of nitrogen dioxide is $200 \mu \mathrm{g} \mathrm{m}^{-3}$ for $1 \mathrm{~h}$ and $40 \mu \mathrm{g} \mathrm{m}^{-3}$ as an annual average (World Health Organization. Regional Office for Europe 2010).

In houses with gas stoves and kerosene heaters, indoor levels often exceed outdoor concentrations. Levy et al. (1998) studied nitrogen dioxide concentrations in indoor ambient of 18 cities in 15 countries, reporting 2-day means ranging from $10 \mathrm{\mu g} \mathrm{m}^{-3}$ to $81 \mathrm{~g} \mathrm{~m}^{-3}$ (5.5 ppb and $45 \mathrm{ppb).} \mathrm{Studies} \mathrm{in} \mathrm{Araraquara,}$ Brazil, showed that the $\mathrm{NO}_{2}$ concentration in a residential kitchen with a gas stove reached 198 ppb $(372 \mu \mathrm{g}$ $\mathrm{m}^{-3}$ ). In an industrial kitchen, the concentration of $\mathrm{NO}_{2}$ reached about $57 \mathrm{ppb}\left(107 \mu \mathrm{g} \mathrm{m}^{-3}\right)$, and in an indoor supermarket parking, the average value was $75 \mathrm{ppb}$ (141 $\mathrm{g} \mathrm{m} \mathrm{m}^{-3}$ ) (Ugucione et al. 2009). Children are more susceptible to respiratory disease and more vulnerable to ambient pollution. Indoor $\mathrm{NO}_{2}$ concentrations were associated with the prevalence of respiratory symptoms, principally in girls. Girls may be more susceptible to indoor air pollution than boys (Shima and Adachi 2000). A study with 352 children in Valencia, Spain, suggested that the nitrogen dioxide outdoor, but not indoor, exposure is associated with a persistent cough during the first year of life (Esplugues et al. 2011). The personal exposure to $\mathrm{NO}_{2}$ generated from various heaters and cooking stoves was studied using 85 university students in Japan. The $\mathrm{NO}_{2}$ concentration during the heating by a kerosene heater and an oil fan heater was 219 and $474 \mu \mathrm{g} \mathrm{m}^{-3}$, respectively. The $\mathrm{NO}_{2}$ level measured during cooking was $290 \mu \mathrm{g} \mathrm{m}^{-3}$ (160 ppb) (Kawamoto et al. 1993).

The monitoring of $\mathrm{NO}_{2}$ is essential to recognize if the regulation is correct or if it should improve. Direct methods based on physical measurements are usually costly, and the alternatives are chemical methods that require previous sampling and preconcentration steps for the determination of $\mathrm{NO}_{2}$ at low concentrations. The most successful chemical methods use the Griess- 
Saltzman (GS) reagent to form a red-pink dye (Saltzman 1954). The intensity of the color is proportional to $\mathrm{NO}_{2}$ concentration, measured as absorbance at $550 \mathrm{~nm}$. The reagent has been used since the 1960s in different chemical methods (Fàbrega et al. 2017; Izumi et al. 2015; Nakano et al. 1998; Ohyama et al. 2000; Passaretti Filho et al. 2015) and also has been included as a recommended chemical method in Methods of Air Sampling and Analysis, a handbook for indoor and outdoor air pollution control (Lodge Jr. 1988). Passive samplers have been extensively used, with the advantage over active sampling, when the objective is to map areas of a city or region with a $\mathrm{NO}_{2}$ higher concentration or to know the average $\mathrm{NO}_{2}$ concentration of indoor environment (Palmes et al. 1976). The analyte is collected over the whole exposure time, and the final concentration of the analyte is determined as a weighted average over the sampling time. The most apparent advantages of passive samplers include small size and weight, low cost, and without the use of an air pump.

Passive sampling is based on molecules flow from a more concentrated to a more diluted region. The schematic diagram of the passive sampler is given in Fig. 1. Ambient air molecules diffuse into the sampler interior until they reach equilibrium between the air outside the sampler. A porous barrier between environmental air and air within the sampler keeps the air in a stagnant state. The concentration of the pollutant in the air, $\mathrm{C}_{\mathrm{X}}$, is the same in the environment and inside the sampler. At the top of the sampler, a sorbent bed traps gas molecules, $\mathrm{n}_{\mathrm{X}}$, with close to $100 \%$ efficiency. The pollutant concentration near the surface of the bed is close to zero $\mathrm{C}_{0, \mathrm{X}}$. If the bed is an efficient collector during sampling, the flow of $\mathrm{NO}_{2}$ molecules from $\mathrm{C}_{\mathrm{X}}$ to $\mathrm{C}_{0, \mathrm{X}}$ is continuous. The number of molecules $\left(\mathrm{n}_{\mathrm{X}}\right)$ collected by the sorbent bed is directly proportional to the diameter of the tube (A), the distance from the absorptive surface to the diffusive membrane $(\mathrm{L})$, the concentration of the pollutant in the air, $\mathrm{C}_{\mathrm{X}}$, and sampling time.

The diffusion of a gas through the tube with $\left(n_{X}\right)$ mols retained in the collecting surface is described by the equation derived from Fick's first law of diffusion (Fick 1855). The equation can determine the average concentration of gas $\mathrm{X}$ in the environment due to the number of mols of gas $\mathrm{X}$ absorbed on the bed surface. The number of molecules $\left(\mathrm{n}_{\mathrm{X}}=\mathrm{n}_{\mathrm{NO} 2}\right)$ can be determined with the Griess-Saltzman reagent, which reacts with $\mathrm{NO}_{2}$ to form a purple azo product (Saltzman 1954). In the last decade, new measurement techniques employing digital image-based (DIB) procedures have been reported for color determination (da Silva and Borges 2019; Kiliç et al. 2018; Moraes et al. 2014; Passaretti Filho et al. 2015; Ravazzi et al. 2018; Šafranko et al. 2018). The technique was recently used to speed up the determination of ozone with a passive sampler (Cerrato-Alvarez et al. 2020; Garcia et al. 2014). The measurement can be carried out using conventional RGB sensors, such as those found in a smartphone camera or scanner. RGB sensors can be useful in environmental analysis when there is no chemical laboratory nearby and/or improve the fast analysis response. The RGB model is used to reproduce the broad color spectrum based on the different combinations of red, green, and blue light. Each channel has 8 bits for red, green, and blue in a 24-bit RGB image; thus, each channel maximum possible range is $0-255$ (as $2^{8}=256$ ). This range means that any given color can be $16,777,216$ possible combinations of $R, G$, and $B$ values (Kohl et al. 2006; Mathews et al. 2004; Soldat et al. 2009). In this article, we combine the use of two userfriendly techniques: passive samplers for gas analysis and color intensity (CI) quantification with a digital image of a cell phone camera.

\section{Materials and Methods}

\subsection{Design of Passive Sampler}

Passive samplers are easy to build. Among the alternatives for its construction, we can mention passive samplers constructed using sections of 38-mm polycarbonate filter holders (Millipore), as described in a previous article published (Garcia et al. 2014). But for the experiments presented in this work, we chose to use the design of passive samplers proposed by Souza et al. (2017). The passive sampler was designed and built with commercial material that is easy to purchase, reducing analysis costs. The parts of the passive sampler are illustrated schematically in Fig. 2. The passive sampler body was made with a 50.0-mL Falcon conical tube used in laboratories (Fig. 2a). The Falcon tube was cut at the 50.0-mL mark, with $1.2 \mathrm{~cm}$ below the edge. If necessary, the cut parts can be sanded to correct irregularities. For each sampler, two Falcon tubes are required to make the pieces. In the first step, a Teflon tape (18 mm wide, $15 \mathrm{~m}$ long, and $0.2 \mathrm{~mm}$ thick) was passed over the cut surface to form a thin membrane. The edges 


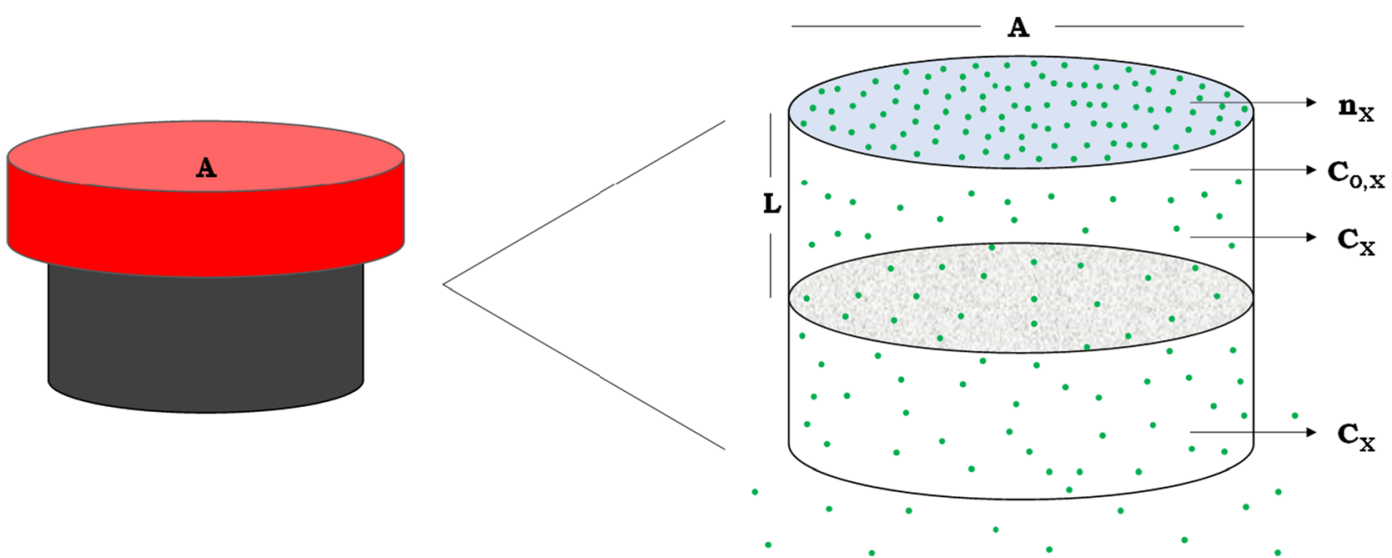

Fig. 1 The diffusion of a gas $\mathrm{X}$ through the sampler tube. $\mathrm{C}_{\mathrm{X}}$ is the gas concentration in the atmosphere; $\mathrm{C}_{0, \mathrm{X}}$ is the concentration of the gas on the sorbent bed; $\mathrm{n}_{\mathrm{X}}$ is the amount of gas $\mathrm{X}$ trapped by the bed; $\mathrm{A}$ is the tube diameter, and $\mathrm{L}$ is the diffusion path length

of the Teflon tape were stretched to cover and seal the entire cylindrical part. The procedure is easy to perform due to the tape malleability, elasticity, and easy adherence to the cylinder edges (Fig. 2b). The two pieces were then joined using black insulating tape, keeping the opposite threads, and creating a single body, the diffusion path (Fig. 2c). Tube caps can be used to close the passive sampler tube on both sides (Fig. 2d).

The passive sampler has $1.3 \mathrm{~cm}$ of the radius (r), and the diffusion path is from the Teflon membrane to cap: (L) of $1.2 \mathrm{~cm}$. A cylinder is formed by the edge of the tube and ends in the Teflon film. The arrangement helps to keep the air stagnant inside the tube.

\subsection{Preparation of $\mathrm{NO}_{2}$ Collecting Solution}

Triethanolamine is a reagent that retains $\mathrm{NO}_{2}$ molecules. The triethanolamine $11 \% \mathrm{v} / \mathrm{v}$ solution was prepared with 5.5-mL triethanolamine (Sigma-Aldrich), $1.75-\mathrm{mL}$ ethylene glycol (Sigma-Aldrich), and 12.5-mL acetone (Sigma-Aldrich). These components were added to a beaker, and a volume of $50 \mathrm{~mL}$ was reached, diluted with deionized water. This final solution was stored in an amber flask inside a refrigerator.

\subsection{Preparation of Griess-Saltzman Gel}

The GS reagent was prepared by dissolving $2.5 \mathrm{~g}$ of sulfanilic acid in $450 \mathrm{~mL}$ of $2.5 \mathrm{~mol} \mathrm{~L}^{-1}$ acetic acid. After dissolution, $10 \mathrm{~mL}$ of a $0.1 \%$ aqueous solution of $\mathrm{N}$-(1-naphthyl)ethylenediamine dihydrochloride was added, and the solution was diluted to $500-\mathrm{mL}$ in a volumetric flask. The solution was stored in an amber bottle inside a refrigerator.

The GS gel reactant was prepared with a $0.6-\mathrm{g}$ Carbopol® 940 polymer in $30 \mathrm{~mL}$ of the GS reagent. Dispersion should be made by the slow addition of the polymer and unstopping stirring to avoid lumps.

\subsection{Calibration of the $\mathrm{NO}_{2}$ with Nitrite Solution}

The $\mathrm{NO}_{2}$ determination with the GS reaction solution is based on the formation of a red-violet dye. The analytical curve was first constructed using the diluted sodium nitrite solution. The calibration by nitrite is based upon the empirical observation that $0.72 \mathrm{~mol}$ of nitrite produces the same color as $1 \mathrm{~mol}$ of $\mathrm{NO}_{2}$ (Lodge Jr. 1988). Stock nitrite solution: dissolve 1.438 -g $\mathrm{NaNO}_{2}$ $\left(68.995 \mathrm{~g} \mathrm{~mol}^{-1}\right)$ in deionized water and make up 0.5 $\mathrm{L}$ in a volumetric flask. This solution is stable for a year if stored in a brown bottle and kept refrigerated. The nitrite working solution was prepared by diluting 0.50 $\mathrm{mL}$ of the stock solution in a $500.0-\mathrm{mL}$ volumetric flask, completed to the mark with deionized water. A $1.0 \mathrm{~mL}$ of the solution produces color equivalent to $83.4 \mu \mathrm{mol}$ $\mathrm{NO}_{2}{ }^{-} 116 \mu \mathrm{mol}$ of $\mathrm{NO}_{2}$. Aliquots of $0.0,0.15,0.3,0.6$, 0.9 , and $1.2 \mathrm{~mL}$ of the nitrite working solution were added to a series of six $5.0-\mathrm{mL}$ volumetric flasks, followed by completion of the volumes with GS reagent. The reading of color was performed after 15 min. For the absorbance measurements of the colored solution, the Hitachi U-2000 spectrophotometer was used. The absorbance measurements were made using a glass cuvette with a light path of $1.0 \mathrm{~cm}$ at a wavelength of $540 \mathrm{~nm}$. 

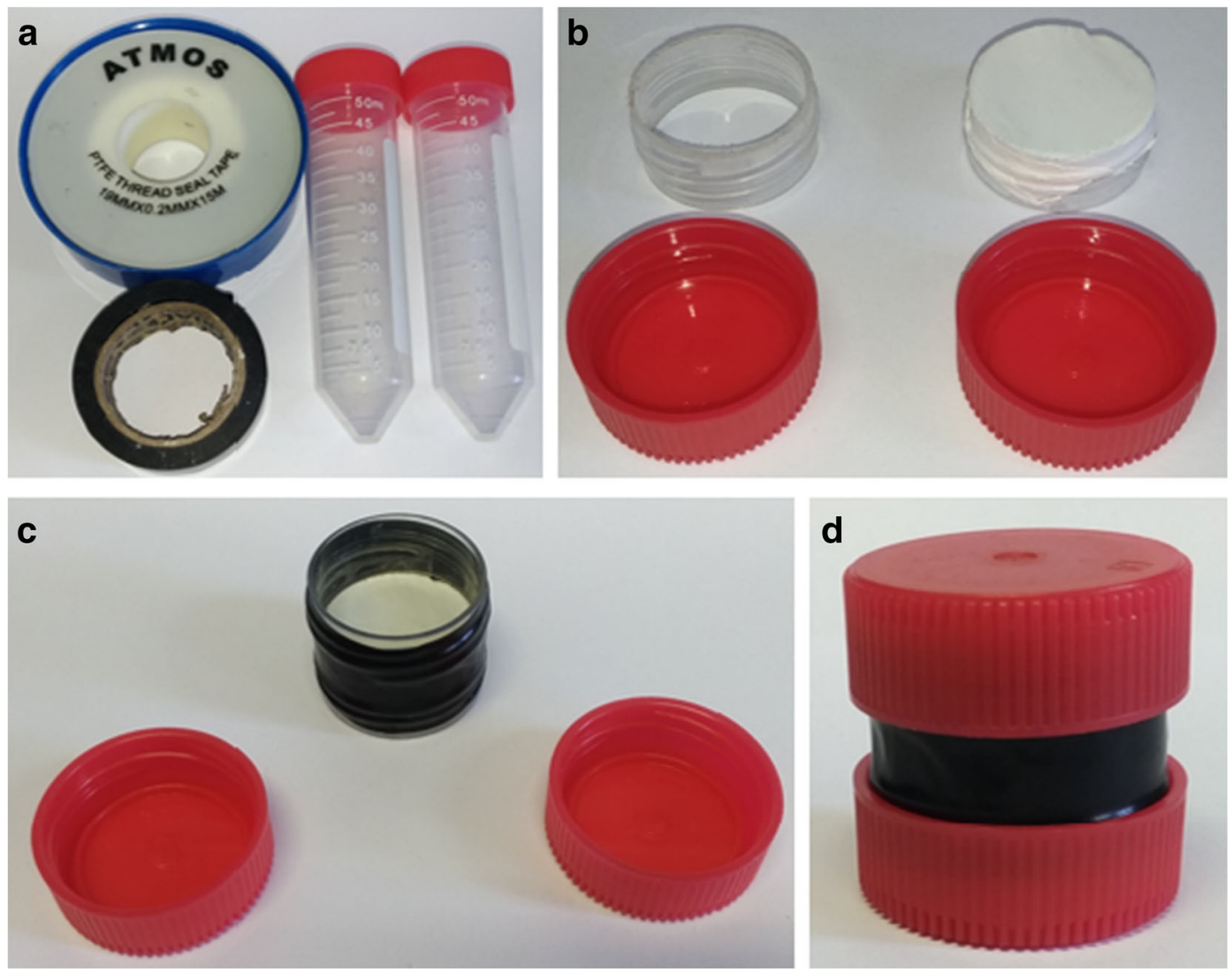

Fig. 2 a Materials used in the construction of the sampler passive sampler; black insulating tape, two $50 \mathrm{~mL}$ Falcon tubes, and Teflon tape. b Two cut pieces, one of which is sealed with Teflon

\subsection{Preparation of the $\mathrm{NO}_{2}$ Sorbent Surface}

Cellulose filters (Whatman 41) are recommended for analytical procedures and used in air pollution analysis as a paper tape for impregnation in sampling procedures. The filters were cut into $2.6-\mathrm{cm}$ diameter circles. This diameter of the cellulose filter allows it to fit inside the tube cap. Each filter was impregnated using an $80-\mu \mathrm{L}$ aliquot of triethanolamine solution. The triethanolamine impregnated filter is placed inside one of the sampler caps with the aid of tweezers. The cap is replaced on the sampler. The passive sampler (Fig. 2d) is ready for use. It should be stored in a closed zip-lock plastic bag and stored in a refrigerator until use.

\subsection{The Use of Passive Sampler in Field Measurements}

For each sampling point, a set of three passive samplers and one field blank were installed under a piece $(10 \times 10$ $\mathrm{cm})$ styrofoam shield to protect from rain during tape. c The two parts were connected, with black insulating tape, forming a single body, the diffusion path. $\mathbf{d}$ Passive sampler ready to use

sampling. The field blank is a passive sampler that was kept sealed during the sampling period.

The measurements were conducted for $8-50 \mathrm{~h}$ periods. At the end of the sampling period, the caps are replaced on the three samplers. The mean of the three replicate measurements was calculated for each sampling.

Cellulose filters are removed from the sampler using tweezers and placed on a clean flat surface (glass plate). Enough gel is added to cover the entire surface of the filter. With a plastic ruler, the GS gel solution is homogeny spread over the filter surface to form a thin reagent layer. After $15 \mathrm{~min}$, the dye reaches its highest CI. In this procedure, the main advantage is that the $\mathrm{NO}_{2}$ contained on the filter surface is directly transformed into the dye. The use of the reagent in gel form prevents capillarity and color dispersion on the filter surface. The result is a uniform color on the filter surface.

The colored filter is inserted into a brown cardboard box to obtain the digital image, sized $14 \mathrm{~cm} \times 13 \mathrm{~cm} \times$ 
$10 \mathrm{~cm}$ (height, length, and width). This box has a light source (high-brightness white LED (10 mm) flashlight) and a rectangular orifice with dimensions $3 \mathrm{~cm} \times 3 \mathrm{~cm}$, where the cell phone camera (Motorola Moto X 2nd generation, 13-Mpx) can be positioned. The color development and capture of the image are illustrated schematically in Fig. 3. The molecular diffusion of $\mathrm{NO}_{2}$ inside the sampler results in the homogeneous collection of gas on the cellulose filter. As a result, the dye forms a homogeneous circular surface until close to the circle edges. We use a square area of $8 \times 8 \mathrm{~mm}$ in the filter center to make the measurements.

After the cell phone captures the image of the color impregnated in the cellulose filters, the corresponding digital image is split to obtain red, green, and blue (RGB) color channels, using a public domain software ImageJ® (v1.52e). However, many cell phone apps found on both Apple Store and Play Store can automatically split RGB channels without capturing the image first.

The most reliable color signal corresponds to the green channel since green is complementary to the red-violet color provided by the formation of dye. The CI, i.e., the product of the digital image signal, was obtained using equation 1 :

$\mathrm{CI}=-\log \left(\mathrm{I} / \mathrm{I}_{0}\right)$

where $\mathrm{I}$ is the signal of the green channel, and $\mathrm{I}_{0}$ is the blank value.

\section{Results and Discussion}

\subsection{Determination of $\mathrm{NO}_{2}$ by Digital Image Analysis}

The challenge was to associate the CI with the known amount of $\mathrm{NO}_{2}$ (calibration curve) for the proposed method. For this purpose, parallel sampling was used. Initially, the average $\mathrm{NO}_{2}$ concentration collected by passive samplers from the first sampling set was determined via spectrometric analysis, as described in Section 2.4. For this, we used the calibration curve constructed with standard nitrite solutions (Eq. 2). Then, following the procedure described in Section 2.6, the CI of the passive samplers of the second set was determined. Each $\mathrm{CI}$ average was assigned the corresponding value of $\mathrm{NO}_{2}$ equivalent to the first set. In this way, the calibration curve for $\mathrm{CI}$ and $\mathrm{NO}_{2}$ was established (Eq. 3):

$$
\begin{aligned}
\mathrm{A}= & 7.940( \pm 0.024) \mathrm{NNO}_{2} \\
& +0,002( \pm 0.002) ;\left(R^{2}=0.9988\right) \\
\mathrm{CI}= & 2.324( \pm 0.0711) \mathrm{N}_{\mathrm{NO} 2} \\
& +0.027( \pm 0.003) ;\left(R^{2}=0.9974\right)
\end{aligned}
$$

where $\mathrm{NNO}_{2}$ is $\mu \mathrm{mol} \mathrm{NO}{ }_{2}^{-}$. Equations 2 and 3 showed that both analytical signal measurements were proportional to the $\mathrm{NO}_{2}{ }^{-}$. The absorbance measure showed the limit of detection, considering that 3.3 times the standard deviation of the blank signal was $0.8 \mathrm{nmol} \mathrm{NO}_{2}{ }^{-}$. For the color intensity, the limit of detection, considering 3.3 times the standard deviation of the blank signal, was $36 \mathrm{nmol} \mathrm{NO}_{2}^{-}$.

The mean $\mathrm{NO}_{2}$ concentration inside the sampler during sampling can be obtained based on Fick's first law of diffusion, using Eq. 4:

$\mathrm{C}_{\mathrm{NO} 2}=\operatorname{In}_{\mathrm{NO} 2} \mathrm{z} /\left(\mathrm{D}_{\mathrm{NO} 2} \pi \mathrm{r}^{2} \mathrm{t}\right)$

where $\mathrm{C}_{\mathrm{NO} 2}$ is the $\mathrm{NO}_{2}$ concentration in ambient air $\left(\mathrm{mol} \mathrm{cm}{ }^{-3}\right), \mathrm{In}_{\mathrm{NO} 2}$ is the amount of $\mathrm{NO}_{2}$ (in mol) that is collected on the absorbent surface, and $\mathrm{D}_{\mathrm{NO} 2 \text {,air }}$ is the coefficient of diffusion of nitrogen dioxide in the air, $0.13361 \mathrm{~cm}^{2} \mathrm{~s}^{-1}$ (Massman 1998). Experiments with gases have shown that local changes during sampling can be neglected (Harper and Purnell 1987). For the passive sampler used in the experiments $(z=1.2 \mathrm{~cm}$, $r=1.3 \mathrm{~cm})$. For a $24-\mathrm{h}$ sampling $(86400 \mathrm{~s}), \mathrm{z} / \mathrm{D}_{\mathrm{NO} 2} \pi \mathrm{r}^{2}$ $t=1.9710^{-5}$, the detection limit is $32 \mu \mathrm{g} \mathrm{m}^{-3}$ (9 ppb) for determination using color intensity.

\subsection{Validation of the Passive Sampler}

The passive sampler validation for its ability to collect $\mathrm{NO}_{2}$ was described in detail in a previous article (Souza et al. 2017). A summary of the procedure for validating is described as follows. The passive samplers set was used in air sampling in the city of Araraquara, Brazil. The samplers were fixed at about $2 \mathrm{~m}$ from the ground, in a place used by the São Paulo State Environmental Company (CETESB) to monitor nitrogen dioxide $(-21.782524 \mathrm{~S},-48.185807 \mathrm{~W})$. The environmental company uses an automatic gas analyzer based on chemiluminescence. The passives sampler was validated by comparing the performance 


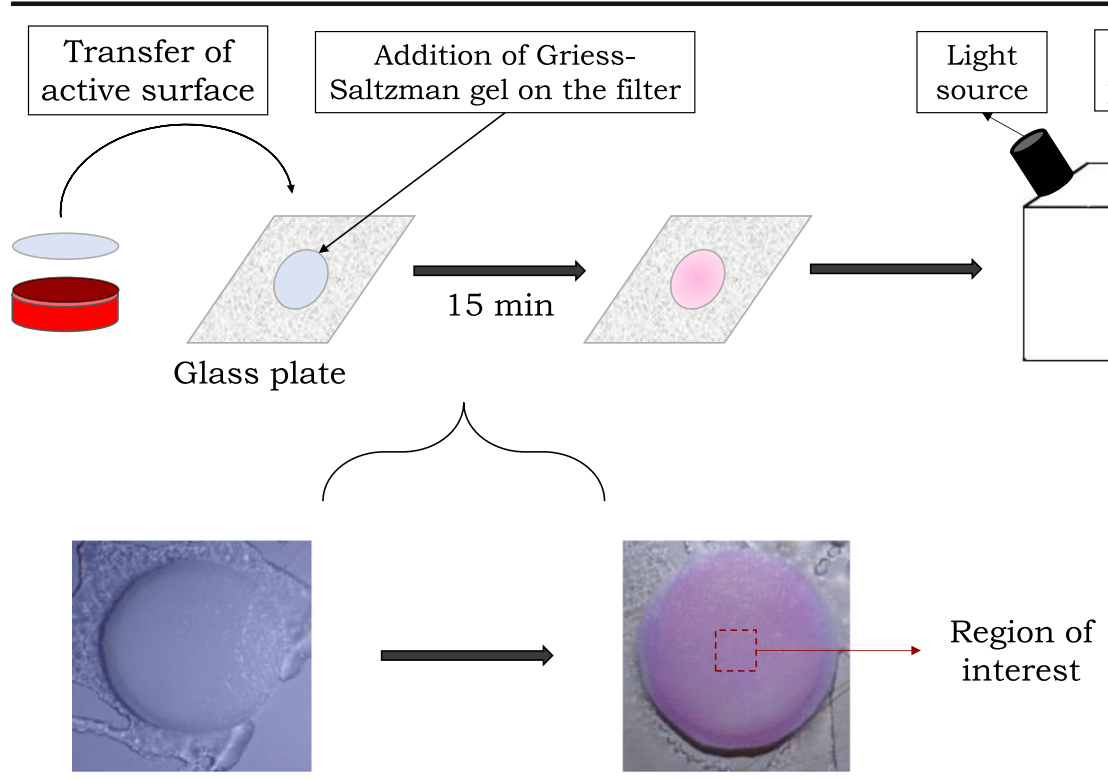

Fig. 3 The cellulose filter is transferred to a glass plate; Griess-Saltzman gel is homogeneously spread over on the filter; wait 15 min for the pinkish color to be developed; then, the filter is placed inside the box, and its image is recorded

with the gas analyzer. The US National Institute of Safety and Health (NIOSH) accepts results with an accuracy (relative standard deviation - RSD) of $\pm 25 \%$ for passive sampler applications in the air (Seethapathy et al. 2008). In this first experiment, at the end of sampling, the samples were taken to the laboratory. The material impregnated in the filters was extracted with deionized water and collected in a 5.0-mL volumetric flask. The volumetric flask was made up to the mark with the GS reagent. The absorbance of the dye formed was measured, and the average atmospheric $\mathrm{NO}_{2}$ concentration was determined by Eq. 1 . Table 1 shows the $\mathrm{NO}_{2}$ concentrations measured by the two different analysis techniques. The relative standard deviation of the two methods was below 25\%, as established by NIOSH. Besides, accuracy assessment (paired samples $t$-test) was performed comparing the $\mathrm{NO}_{2}$ concentration obtained by both active and passive sampling, and the results agreed at the $95 \%$ confidence level. Consequently, passive samplers can be used for sampling $\mathrm{NO}_{2}$.

In the following experiment, the $\mathrm{NO}_{2}$ concentrations obtained from passive samplers were compared by direct measurements of color intensity on the surface of the cellulose filter and the absorbance obtained with the analyte extraction. In these experiments, two sets of passive samplers were fixed on the fence that separates the Chemistry Institute from the street where cars and buses transit regularly. At the end of the sampling, one of the passive samplers' sets was analyzed by extracting the analyte and determining the solution absorbance. For the second set, cellulose filters are removed from the sampler and placed on a clean glass plate. The gel solution is homogeny spread over the filter surface to form a thin reagent layer. After $15 \mathrm{~min}$, the intensity of color was measured, following the procedure schematically illustrated in Fig. 3. The data obtained by both techniques showed that the results are similar and statistically comparable. By applying the paired samples $t$ -

Table $1 \mathrm{NO}_{2}$ concentration obtained by both passive and active sampling (Souza et al. 2017)

\begin{tabular}{llll}
\hline Sampling time $(\mathrm{h})$ & \multicolumn{2}{l}{$\mathrm{NO}_{2}$ concentration $\left(\mu \mathrm{g} \mathrm{m}^{-3}\right)$} & \\
\cline { 2 - 3 } & $\begin{array}{l}\text { Passive } \\
\text { sampling }\end{array}$ & $\begin{array}{l}\text { Active } \\
\text { sampling }\end{array}$ & \\
\hline 29.9 & $15.7 \pm 2.8$ & 12.4 & 22.2 \\
32.3 & $18.3 \pm 0.8$ & 13.3 & 5.6 \\
42.4 & $24.8 \pm 2.2$ & 27.9 & 8.1 \\
51.5 & $28.1 \pm 4.3$ & 34.9 & 12.4 \\
77.5 & $18.7 \pm 1.8$ & 16.0 & 10.9 \\
100 & $22.4 \pm 0.7$ & 22.5 & 3.0 \\
\hline
\end{tabular}


Fig. 4 Comparison of the results obtained using the spectrophotometric and image analysis methods. Sampling duration and days (in 2016): (1) $14 \mathrm{~h}, 5$ September; (2) $27 \mathrm{~h} 6 \mathrm{~min}$, 29 to 30 September; (3) $24 \mathrm{~h}$ $43 \mathrm{~min}, 8$ to 9 September; (4) $50 \mathrm{~h}$ 56min, 29 to 1 December; (5) $48 \mathrm{~h}$ $29 \mathrm{~min}, 24$ to 26 August

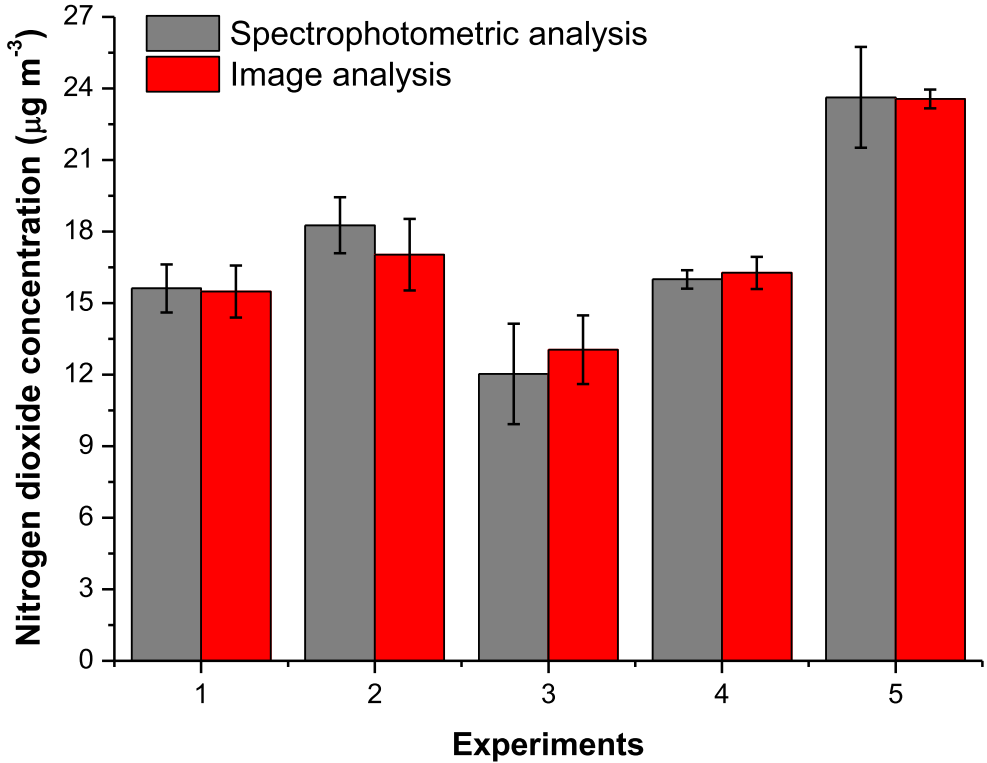

test, it was not statistically distinguishable at the $95 \%$ confidence level (Fig. 4).

The advantage of using this method is that the solution handling is minimal, and the determination can be made using any cell phone with a camera.

\section{Conclusion}

The proposed method is simple, fast, and does not require laboratory equipment, such as a spectrophotometer, therefore having a low usability cost. It fits any smartphone with a camera. There are plenty of apps available that automatically split RGB color channels, skipping the step of taking the picture and then processing the image. This method can be applied for both outside and indoor environments, in particular for low budget laboratories.

Supplementary Information The online version contains supplementary material available at https://doi.org/10.1007/s11270021-05031-4.

Funding The Brazilian agencies provided financial support for this works: CAPES Coordenação de Aperfeiçoamento de Pessoal de Nível Superior and CNPq Conselho Nacional de Desenvolvimento Científico e Tecnológico proc 481505/2013-0 and proc 310065/2016-0

\section{References}

Ahmad, S. S., Biiker, P., Emberson, L., \& Shabbir, R. (2011). Monitoring nitrogen dioxide levels in Urban Areas in Rawalpindi, Pakistan. Water, Air, and Soil Pollution, 220(1-4), 141-150. https://doi.org/10.1007/s11270-0110741-9.

Allen, A. G., Machado, C. M. D., \& Cardoso, A. A. (2011). Measurements and modeling of reactive nitrogen deposition in southeast Brazil. Environmental Pollution, 159(5), 1190 1197. https://doi.org/10.1016/j.envpol.2011.02.002.

Arbex, M. A., Martins, L. C., Pereira, L. A. A., Negrini, F., Cardoso, A. A., Melchert, et al. (2007). Indoor $\mathrm{NO}_{2}$ air pollution and lung function of professional cooks. Brazilian Journal of Medical and Biological Research, 40(4), 527534. https://doi.org/10.1590/S0100-879X2007000400011.

Beelen, R., Hoek, G., van den Brandt, P. A., Goldbohm, R. A., Fischer, P., Schouten, L. J., et al. (2008). Long-term effects of traffic-related air pollution on mortality in a Dutch cohort (NLCS-AIR study). Environmental Health Perspectives, 116(2), 196-202. https://doi.org/10.1289/ehp.10767.

Cerrato-Alvarez, M., Frutos-Puerto, S., Miró-Rodríguez, C., \& Pinilla-Gil, E. (2020). Measurement of tropospheric ozone by digital image analysis of indigotrisulfonate-impregnated passive sampling pads using a smartphone camera. Microchemical Journal, 154(November 2019), 104535. https://doi.org/10.1016/j.microc.2019.104535.

CETESB. (2019). Qualidade do ar do estado de São Paulo 2019. São Paulo. https://cetesb.sp.gov.br/ar/wpcontent/uploads/sites/28/2020/07/Relatório-de-Qualidadedo-Ar-2019.pdf. Accessed 3 Sept 2020.

da Silva, R. S., \& Borges, E. M. (2019). Quantitative analysis using a flatbed scanner: Aspirin quantification in pharmaceutical tablets. Journal of Chemical Education, 96(7), 15191526. https://doi.org/10.1021/acs.jchemed.8b00620. 
Esplugues, A., Ballester, F., Estarlich, M., Llop, S., FuentesLeonarte, V., Mantilla, E., et al. (2011). Outdoor, but not indoor, nitrogen dioxide exposure is associated with persistent cough during the first year of life. Science of the Total Environment, 409(22), 4667-4673. https://doi.org/10.1016/j. scitotenv.2011.08.007.

Fàbrega, C., Fernández, L., Monereo, O., Pons-Balagué, A., Xuriguera, E., Casals, O., et al. (2017). Highly specific and wide range NO2 sensor with color readout. ACS Sensors, 2(11), 1612-1618. https://doi.org/10.1021/acssensors.7 b00463

Fick, A. (1855). V. On liquid diffusion. The London, Edinburgh, and Dublin Philosophical Magazine and Journal of Science, 10 (63), 30-39. https://doi.org/10.1080 $/ 14786445508641925$.

Filleul, L., Rondeau, V., Vandentorren, S., Le Moual, N., Cantagrel, A., Annesi-Maesano, I., et al. (2005). Twenty five year mortality and air pollution: Results from the French PAARC survey. Occupational and Environmental Medicine, 62, 453-460. https://doi.org/10.1136 /oem.2004.014746.

Finlayson-Pitts, B. J., \& Pitts, J. N. (1997). Tropospheric air pollution: Ozone, airborne toxics, polycyclic aromatic hydrocarbons, and particles. Science, 276(5315), 1045-1052. https://doi.org/10.1126/science.276.5315.1045.

Garcia, G., Allen, A. G., \& Cardoso, A. A. (2014). A new and simple visual technique based on indigo dye for determination of ozone in ambient air. Water, Air, and Soil Pollution, 225(2). https://doi.org/10.1007/s11270-013-1836-2.

Gauderman, W. J., Avol, E., Lurmann, F., Kuenzli, N., Gilliland, F., Peters, J., \& McConnell, R. (2005). Childhood asthma and exposure to traffic and nitrogen dioxide. Epidemiology, 16(6), 737-743. https://doi.org/10.1097/01. ede.0000181308.51440.75.

Giannadaki, D., Giannakis, E., Pozzer, A., \& Lelieveld, J. (2018). Estimating health and economic benefits of reductions in air pollution from agriculture. Science of the Total Environment, 622-623, 1304-1316. https://doi.org/10.1016/j. scitotenv.2017.12.064.

Harper, M., \& Purnell, C. J. (1987). Diffusive sampling - a review. American Industrial Hygiene Association Journal, 48 (3), 214-218. https://doi.org/10.1080 $/ 15298668791384652$.

Henschel, S., Le Tertre, A., Atkinson, R. W., Querol, X., Pandolfi, M., Zeka, A., et al. (2015). Trends of nitrogen oxides in ambient air in nine European cities between 1999 and 2010. Atmospheric Environment, 117, 234-241. https://oi. org/10.1016/j.atmosenv.2015.07.013.

Hůnová, I., Bäumelt, V., \& Modlík, M. (2020). Long-term trends in nitrogen oxides at different types of monitoring stations in the Czech Republic. Science of the Total Environment, 699, 134378. https://doi.org/10.1016/j.scitotenv.2019.134378.

International Energy Statistics-US Energy Information Administration (EIA). (n.d.). https://www.eia. gov/international/overview/world. Accessed 4 June 2020

Izumi, K., Utiyama, M., \& Maruo, Y. Y. (2015). Colorimetric NOx sensor based on a porous glass-based NO2 sensing chip and a permanganate oxidizer. Sensors and Actuators, B: Chemical, 216(2), 128-133. https://doi.org/10.1016/j. snb.2015.04.029.
Kawamoto, T., Matsuno, K., Arashidani, K., et al. (1993). Personal exposure to nitrogen dioxide from indoor heaters and cooking stoves. Archives of Environmental Contamination and Toxicology, 25, 534-538. https://oi. org/10.1007/BF00214345.

Khoo, A. (2020). Coronavirus lockdown sees air pollution plummet across UK. BBC News. https://www.bbc.com/news/ukengland-52202974. Accessed 6 July 2020

Kiliç, V., Alankus, G., Horzum, N., Mutlu, A. Y., Bayram, A., \& Solmaz, M. E. (2018). Single-image-referenced colorimetric water quality detection using a smartphone. ACS Omega, 3(5), 5531-5536. https://doi.org/10.1021/acsomega.8 b00625.

Kohl, S. K., Landmark, J. D., \& Stickle, D. F. (2006). Demonstration of absorbance using digital color image analysis and colored solutions. Journal of Chemical Education, 83(4), 644-646.

Levy, J. I., Lee, K., Spengler, J. D., \& Yanagisawa, Y. (1998). Impact of residential nitrogen dioxide exposure on personal exposure: an international study. Journal of the Air and Waste Management Association, 48(6), 553-560. https://doi.org/10.1080/10473289.1998.10463704.

Lodge Jr., J. P. (1988). In J. P. Lodge Jr. (Ed.), Methods of Air Sampling and Analysis (3rd ed.). New York: Routledge. https://doi.org/10.1201/9780203747407.

Machado, C. M. D., Cardoso, A. A., \& Allen, A. G. (2008). Atmospheric emission of reactive nitrogen during biofuel ethanol production. Environmental Science and Technology, 42(2), 381-385. https://doi.org/10.1021 /es070384u.

Martin, P., Cabañas, B., Villanueva, F., Gallego, M. P., Colmenar, I., \& Salgado, S. (2010). Ozone and nitrogen dioxide levels monitored in an urban area (Ciudad Real) in central-southern Spain. Water, Air, and Soil Pollution, 208(1-4), 305-316. https://doi.org/10.1007/s11270-009-0168-8.

Massman, W. J. (1998). A review of the molecular diffusivities of $\mathrm{H} 2 \mathrm{O}, \mathrm{CO} 2, \mathrm{CH} 4, \mathrm{CO}, \mathrm{O} 3, \mathrm{SO} 2, \mathrm{NH} 3, \mathrm{~N} 2 \mathrm{O}, \mathrm{NO}$, and $\mathrm{NO} 2$ in air, $\mathrm{O} 2$ and $\mathrm{N} 2$ near STP. Atmospheric Environment, 32(6), 1111-1127. https://doi.org/10.1016 /S1352-2310(97)00391-9.

Mathews, K. R., Landmark, J. D., \& Stickle, D. F. (2004). Quantitative assay for starch by colorimetry using a desktop scanner. Journal of Chemical Education, 81(5), 702-704.

Moraes, E. P., Da Silva, N. S. A., De Morais, C. D. L. M., Das Neves, L. S., \& De Lima, K. M. G. (2014). Low-cost method for quantifying sodium in coconut water and seawater for the undergraduate analytical chemistry laboratory: flame test, a mobile phone camera, and image processing. Journal of Chemical Education, 91(11), 1958-1960. https://doi. org/10.1021/ed400797k.

Nakano, N., Yamamoto, A., Kawabe, T., \& Nagashima, K. (1998). An automatic measurement of formaldehyde in air by a monitoring tape method. Nippon Kagaku Kaishi / Chemical Society of Japan - Chemistry and Industrial Chemistry Journal, 7, 509-510. https://doi.org/10.1246 /nikkashi.1998.506.

Ogen, Y. (2020). Assessing nitrogen dioxide (NO2) levels as a contributing factor to coronavirus (COVID-19) fatality. Science of the Total Environment, 726, 138605. https://doi. org/10.1016/j.scitotenv.2020.138605. 
Ohyama, T., Maruo, Y. Y., Tanaka, T., \& Hayashi, T. (2000). A ppb-level NO2 detection system using coloration reactions in porous glass and its humidity dependence. Sensors and Actuators, B: Chemical, 64(1-3), 142-146. https://doi. org/10.1016/S0925-4005(99)00497-9.

Palmes, E. D., Gunnison, A. F., Dimattio, J., \& Tomczyk, C. (1976). Personal sampler for nitrogen dioxide. American Industrial Hygiene Association Journal, 37(10), 570-577. https://doi.org/10.1080/0002889768507522.

Passaretti Filho, J., Petruci, J. F. d. S., \& Cardoso, A. A. (2015). Development of a simple method for determination of $\mathrm{NO} 2$ in air using digital scanner images. Talanta, 140(2), 73-80. https://doi.org/10.1016/j.talanta.2015.03.009.

Ravazzi, C. G., de Oliveira Krambeck Franco, M., Vieira, M. C. R., \& Suarez, W. T. (2018). Smartphone application for captopril determination in dosage forms and synthetic urine employing digital imaging. Talanta, 189, 339-344. https://doi.org/10.1016/j.talanta.2018.07.015.

Šafranko, S., Živković, P., Stanković, A., Medvidović-Kosanović, M., Széchenyi, A., \& Jokić, S. (2018). Designing ColorX, image processing software for colorimetric determination of concentration, to facilitate students' investigation of analytical chemistry concepts using digital imaging technology. Journal of Chemical Education. https://doi.org/10.1021/acs. jchemed.8b00920.

Saltzman, B. E. (1954). Colorimetric microdetermination of nitrogen dioxide in the atmosphere. Analytical Chemistry, 26(12), 1949-1955. https://doi.org/10.1021/ac60096a025.

Seethapathy, S., Górecki, T., \& Li, X. (2008). Passive sampling in environmental analysis. Journal of Chromatography $A$, 1184(1-2), 234-253. https://doi.org/10.1016/j. chroma.2007.07.070.

Shima, M., \& Adachi, M. (2000). Effect of outdoor and indoor nitrogen dioxide on respiratory symptoms in schoolchildren. International Journal of Epidemiology, 29(5), 862-870. https://doi.org/10.1093/ije/29.5.862.

Soldat, D. J., Barak, P., \& Lepore, B. J. (2009). Microscale colorimetric analysis using a desktop scanner and automated digital image analysis. Journal of Chemical Education, 86(5), 617-620. https://doi.org/10.1021/ed086p617.
Souza, P. A. F., Francisco, K. C. A., \& Cardoso, A. A. (2017). Development of sensitive passive sampler for nitrogen dioxide air pollution monitoring. Quimica Nova, 40(10), 1233 1237. https://doi.org/10.21577/0100-4042.20170117.

Tong, D. Q., Lamsal, L., Pan, L., Ding, C., Kim, H., Lee, P., et al. (2015). Long-term NOx trends over large cities in the United States during the great recession: comparison of satellite retrievals, ground observations, and emission inventories. Atmospheric Environment, 107, 70-84. https://doi. org/10.1016/j.atmosenv.2015.01.035

Ugucione, C., Machado, C. M. D., \& Cardoso, A. A. (2009). Avaliação de NO2 na atmosfera de ambientes externos e internos na cidade de Araraquara, São Paulo. Química Nova, 32(7), 1829-1833. https://doi.org/10.1590/S010040422009000700027.

Warashina, M., Tanaka, M., Tsujino, Y., Mizoguchi, T., Hatakeyama, S., \& Maeda, Y. (2001). Atmospheric concentrations of sulfur dioxide and nitrogen dioxide in China and Korea measured by using the improved passive sampling method. Water, Air, \& Soil Pollution, 130(January), 15051510. https://doi.org/10.1023/A:1013941820431.

World Health Organization. (2000). Air Quality Guidelines for Europe. Copenhagen: World Health Organization. https://doi.org/10.1007/BF02986808.

World Health Organization. (2006). WHO Air quality guidelines for particulate matter, ozone, nitrogen dioxide and sulfur dioxide: Global update 2005: Summary of risk assessment. Geneva: World Health Organization. Copenhagen, Denmark. https://doi.org/10.1016/0004-6981(88)90109-6.

World Health Organization. Regional Office for Europe. (2010). WHO guidelines for indoor air quality: selected pollutants. World Health Organization. Copenhagen: World Health Organization. Regional Office for Europe. https://apps.who. int/iris/bitstream/handle/10665/260127/9789289002134eng.pdf?sequence=1\&isAllowed=y. Accessed 20 July 2020.

Publisher's Note Springer Nature remains neutral with regard to jurisdictional claims in published maps and institutional affiliations. 